\title{
Importance of Diagnosis and Treatment in the Anomaly of the Right Coronary Artery: A Literature Review
}

\author{
Eduardo Massaro Yamashita ${ }^{1}$, Lissandro Danny Souza dos Santos $^{2}$, Leandro Roberto Wojcik ${ }^{3}$, Emerson \\ Schindler Júnior ${ }^{4}$ \\ ${ }^{1}$ Positivo University, School of Medicine, Curitiba, Paraná, Brazil, E-mail ID: eduardoyamashita@terra.com.br \\ ${ }^{2,3,4}$ Positivo University, School of Medicine, Curitiba, Paraná, Brazil
}

\begin{abstract}
Objective: Perform a literature review on the importance of diagnosis and treatment in the right coronary artery anomaly. Methods: This is a bibliographic review through scientific publications related to the theme on the importance of diagnosis and treatment in the right coronary artery anomaly. The inclusion criteria for the articles were established as follows: to be a research article published in national journals in Portuguese, English and Spanish between 2015 and 2020. The databases used to research the topic were: LILACS (Latin American and Caribbean Literature in Social and Health Sciences) and Scielo (Scientific Eletronic Library Online) for data collection, based on the following descriptors: Anomaly, Coronary, Diagnosis. Bibliographic Review: Anomalies in the coronary arteries are called congenital changes according to their origin, course and disposition of the epicardial coronary arteries. Anomalies are categorized according to the parameters of clinical complication. In cases of anomalies of the right coronary artery, where there are no responsible epicardial arteries that irrigate the territories dependent on the anterior and circumflex descendant, which associated with age and other factors of the symptoms makes this case rare. Conclusion: This study allows to conclude that it is possible the anomalies of the coronary arteries are rare, being able to be asymptomatic and it is a pathology that affects a portion of young athletes, with a healthy history.
\end{abstract}

Keywords: Anomaly, Coronary, Diagnosis

\section{Introduction}

Anomalies of the coronary arteries (CAA) are called congenital changes according to their origin, course and disposition of the epicardial coronary arteries (CA). CAA, occur in less than $1 \%$ of the world population, and at the present time, no data is found that indicate a difference in incidence between different races. [1]-[2]

CAA can be detected benignly or in its severe state, which can cause myocardial ischemia, infarction and sudden death. Its origin and the proximal path of the CAA are the first predictors of its magnitude. Thus, complementary clinical examinations, especially those of cardiovascular imaging, assist as essential tools for diagnosis. [3]

Anomalies are categorized according to the parameters of clinical complication. Therefore, the anomalies are composed of the coronary arteries resulting from the pulmonary artery, congenital atresia of the coronary trunk, coronary fistulas, coronary arteries becoming myocardial bridges, coronary artery aneurysms and coronary artery stenosis.[4]-[5]

They are mentioned in the literature in which anomalies in which the right coronary artery (RCA) where the right coronary sinus is at a proximal bifurcation or is prolonged in the distal branch with anterior descending and circumflex origin. These present anomaly is characterized as a single coronary ostio because the anterior descending and circumflex arteries are in place, but their origin and path are anomalous. [6]
In these cases of anomalies, there are no active epicardial articles that cause irrigation of territories dependent on the anterior and circumflex descendant, or that are associated with age and other symptomatic factors that begin in this case. As CA is subdivided into greater or lesser, causing disorders of myocardial perfusion and as non-significant or lesser, they are those in which the coronary flow is normally designated. [7]. The objective of this work is to elucidate through the literature an effective diagnosis in conjunction with an appropriate treatment in cases of anomaly of the right coronary artery.

\section{Methods}

This is a bibliographic review through scientific publications related to the theme on the importance of diagnosis and treatment in the right coronary artery anomaly. The inclusion criteria for the articles were established as follows: to be a research article published in national journals in Portuguese, English and Spanish between 2015 and 2020. The databases used to research the topic were: LILACS (Latin American and Caribbean Literature in Social and Health Sciences) and Scielo (Scientific Eletronic Library Online) for data collection, based on the following descriptors: Anomaly, Coronary, Diagnosis.

During the collection and analysis of the material, articles were collected, and those that, when reading the abstract, were not related to a study problem were excluded. For analysis and analysis of the material, the following procedures were performed: informative or exploratory

Volume 9 Issue 8, August 2020 


\section{International Journal of Science and Research (IJSR) \\ ISSN: 2319-7064}

ResearchGate Impact Factor (2018): 0.28 | SJIF (2019): 7.583

reading, which registered in the reading of the material for the saber that treated the articles; selective reading, concerned with the description and selection of the material as to its relevance for the study; critical and reflective reading that seeks through the data and construction of the results found.

\section{Bibliographic Review}

The heart is determined from the splenic mesoderm formed on the pericardial floor, a region known as the cardiac area, initiating two endocardial tubes that will be joined to form the primitive cardiac tube. An anomaly of CA in the aortic sinus is rare, a literature indicates an estimated incidence of $0.2 \%$ to $5.6 \%$ for the right coronary originating from the left aortic sinus. [2]-[8]

As it demonstrates a low incidence of incidence, as CA presents a great risk of sudden death, it causes myocardial ischemia in cumulative results that in the long run, derive into myocardial fibers determining lethal ventricular arrhythmias, by generating a substrate to the unstable myocardium in its electroconduction. [9]

The anomalous origin of the right coronary sinus artery is related to sudden death in $59 \%$ of cases, due to people who do physical activity. In sudden deaths, there are different paths such as the beginning of the pulmonary artery and posteriorly to the aorta, the intra-septal between the aorta and the pulmonary artery and interarterial from the pulmonary aorta. [10]

In addition to physical activity, there are other mechanisms such as acute angle and fold / occlusion due to the angulation of coronary arteries [11], coronary spasm by its torsional movement [12], mechanical compression of the anomalous artery in the trunks of the pulmonary and aortic arteries on exertion [13], intramural arterial portion [14], further aggravating a coronary obstruction, mainly with aortic expansion on exertion [15].

In some cases, the surgical cut of the pericardium is associated with coronary revascularization, performed with a graft from adjacent arteries such as the mammary artery for CAD and an obstruction of anomalous origin. There are factors that help with possible complications over time, such as increased pressure in the cardiac chambers. [16]

Fazzio (2017) found that a large part of patients with a right coronary originated the left sinus, had interaterial movement. The main risk characteristics of this abnormal coronary screening are the lateral luminal pressure of the intramural vessel substance in the anomaly, a coronary compression between the aorta and a pulmonary artery. [17]

In order to be investigated or prognosis of some CAA, it is indicated the need to search for screening methods, ideally non-invasive, as well as to define the target population of this screening. $\mathrm{Bu}$ (2020) emphasizes the use of angiotomography that allows a potential non-invasive diagnosis, helping in the origin of CA. Therefore, its use in the diagnosis and the standard exam in identifying and characterizing it as CAA. [18]

Thus, an angiotomography offers a three-dimensional selection of the anatomical connections between the CA and the structures that make up the cardiorespiratory plexus, cuts of the cardiac structures at different angles. However, this method can be seen as a primary form of imaging to describe coronary vessel pathologies. [18]

Neves (2015) mentions that imaging tests are indispensable for the diagnosis of CAA, as it is possible to confirm the diagnosis only by anamnesis. Magnetic resonance imaging (MRI) is mentioned as an exam that accompanies an angiotomography, as it is not invasive and demonstrates origin and examination of the coronary arteries, but its resolution is less and less than the new methods, being described as an exam. that complements an angiotomography. [3]

Knowing the advantages of CT scans, there are disadvantages in relation to MRI, which is the use of ionizing radiation. New techniques already exist that allow the reduction of the radiation dose, even lower than the radiation used in digital coronary angiography exams, maintaining resolution and patient safety. [19]

With the number of applicable tests, functional diagnostic methods, such as myocardial scintigraphy, stress magnetic resonance and intravascular ultrasound, are used to assess myocardial ischemia or fibrosis associated with therapy. [18]

Antonio (2016) demonstrated a clinical case in which the patient already presented hypertension, smoking and chest pain, however, blood pressure and heart rate were normal and without murmurs, such as pulmonary auscultation in his healthy patterns. Due to the doubtful picture, the patient underwent a radial cineangiocoronariography with an introducer together with a catheter, which showed an RCA resulting from intercoronary communication without injuries, so, echocardiography under stress with negative result was performed. [20]

The use of a catheter is rare and is necessary in cases of difficult diagnosis, where only $0.02 \%$ of cardiac catheterizations are obtained as a diagnosis in relation to intercoronary communication, corresponding to 1 in every 5,000 exams of normal coronary angiography. [21]

The resistance of intercoronary communication is representative of an epidemic coronary artery in an angiographic form that is present in normal vessels, however, there are rare reports that the progress of intercoronary communication in the absence of obstructive coronary disease, can happen as a result of spasms. [21]

The definitive treatment of coronary anomaly, on the other hand, must be guided by its origin, or rather, by the anomalous artery and its anatomy required for attention in a new application, if any. There is a performance of surgeries that perform the reconstruction / decompression of its tracking, reimplanting the coronary into the appropriate coronary sinus or even myocardial revascularization. [22]

\section{Volume 9 Issue 8, August 2020}




\section{International Journal of Science and Research (IJSR)}

ISSN: 2319-7064

ResearchGate Impact Factor (2018): 0.28 | SJIF (2019): 7.583

In some cases there is a need for the use of stents that perform dilations in some lesions, which contain a pharmacological aid, in which they work as an immunosuppressant to prevent rejection and also as an antineoplastic agent. Even with cases in which the inclusion of stents is necessary, imaging tests pre-determine their usability. [23]

In intercoronary communications, patients demonstrate effective treatment after the use of beta-blockers or calcium channel antagonists, to assist any mechanism that reduces the vasomotor bonus and prevents ischemia in conjunction with RCA. [20]

With the appearance of CT in conjunction with electrocardiogram, it is possible to non-invasively detect the origin, which, unlike surgery and the use of catheters, the course and branching of the CA of origin of the RCA can be diagnosed and treated at a lower speed. [22]

Other important data is the use of the Takeuchi procedure that recovers the double coronary perfusion. In children, it is possible to implant an anomalous coronary artery in the aorta or to make an intrapulmonary access to the left coronary ostium of the aorta. In adults, the coronary artery is connected to the pulmonary artery in conjunction with the use of a mammary artery graft. [6]

In fact, even with success in the treatment methods, it still depends on the myocardial circumstance not instant in the diagnosis and how it can affect the individual's clinical case. Thus, the longer the diagnosis will take, the greater the number of injuries caused by this non-myocardial pathology such as ischemia and ventricular dysfunctions, reaching a difficult recovery prognosis. [18]-[22]-[23]

\section{Conclusion}

The CAA is rare, can be asymptomatic and is a pathology that accommodates a portion of young athletes, with a healthy history. Despite its rarity, there are questionable data regarding incidence and screening. As soon as possible to make the diagnosis, it is possible to contribute to an improvement and an effective treatment in the face of several available forms, such as surgeries and correction procedures in the face of anomalies.

The importance of science was selected in search of literatures that contributed to an explanation regarding cardiac pathologies in current data, that deepened or knew the existing procedures and that are not invasive for the continuous improvement of the patient.

\section{References}

[1] CERBinO, F. E., CAMARGO, G. C., DE CARVAlHO, F. P., GOTTLIEB, I. Rara Anomalia Coronariana em Jovem com Dor Torácica Atípica. Departamento de Imagem Cardiovascular, p. $195,2015$.
[2] SILVA, A., BAPTISTA, M. J., ARAÚJO, E. Anomalias congénitas das artérias coronárias. Revista Portuguesa de Cardiologia, v. 37, n. 4, p. 341-350, 2018.

[3] NEVES, P. O., ANDRADE, J., MONÇÃO, H. Artérias coronárias anômalas: o que o radiologista precisa saber. Radiologia Brasileira, v. 48, n. 4, p. 233-241, 2015.

[4] MICHALOWSKA, I. M., HRYNIEWIECKI, T., KWIATEK, P., STOKLOSA, P., SWOBODA-RYDZ, U., SZYMANSKI, P. Coronary artery variants and anomalies in patients with bicuspid aortic valve. Journal of Thoracic Imaging, v. 31, n. 3, p. 156-162, 2016.

[5] NAITO, S., PETERSEN, J., REICHENSPURNER, H., GIRDAUSKAS, E. The impact of coronary anomalies on the outcome in aortic valve surgery: comparison of bicuspid aortic valve versus tricuspid aortic valve morphotype. Interactive cardiovascular and thoracic surgery, v. 26, n. 4, p. 617-622, 2018.

[6] NUNES, A., ARAÚJO, P., RESENDE, C. X., PINHO, T., DIAS, P., MACIEL, M. J. Oclusão ostial iatrogênica do tronco da coronária esquerda e da coronária direita após substituição cirúrgica da válvula aórtica. J Transcat Intervent, v. 28, p. -, 2020.

[7] MALAKAR, A. K., CHOUDHURY, D., HALDER, B., PAUL, P., UDDIN, A., CHAKRABORTY, S. A review on coronary artery disease, its risk factors, and therapeutics. Journal of cellular physiology, v. 234, n. 10, p. 16812-16823, 2019.

[8] BENJAMIN, E. J., VIRANI, S. S., CALlAWAY, C. W., CHAMBERLAIN, A. M., CHANG, A. R., CHENG., et al. Heart disease and stroke statistics2018 update: a report from the American Heart Association. Circulation, 2018.

[9] KATO, M. NAREMATSU, M. NAKAJIMA, Y. Anatomy of the coronary artery and cardiac vein in the quail ventricle: Patterns are distinct from those in mouse and human hearts. Anatomical science international, v. 93, n. 4, p. 533-539, 2018.

[10] RAMÍREZ, E., MONTOYA, M., VÉLEZ, A. Coronaria derecha de origen anómalo en adulto. Revista Colombiana de Cardiología, v. 22, n. 1, p. 49-53, 2015.

[11]PAUlA, J. E. T. D., FALCÃO, B. D. A. A., SILVA, A C. B. D. Técnica retrógrada para tratamento percutâneo das oclusões coronárias crônicas. J Transcat Intervent, v. 28, p. -, 2020.

[12] CANDELARIO, R. V. Síndrome X de microcirculación coronaria, espasmo coronario e infarto agudo de miocardio en pacientes sin lesiones coronarias significativas. CorSalud, v. 10, n. 2, p. 170-173, 2018.

[13]FERREIRA, A. F. P., ROSEMBERG, S., OLIVEIRA, D. S., ARAUJO-FILHO, J. D. A. B., NOMURA, C. H. Origem anômala de artérias coronarianas com trajeto interarterial: ensaio iconográfico. Radiologia Brasileira, v. 52, n. 3, p. 193-197, 2019.

[14]MORAES, H. A. Descrição do protocolo de angiotomografia das artérias coronárias para o estudo da doença arterial coronariana. 2018.

[15] REIS, M. S., DE MELO, R. C., QUITÉRIO, R. J., DE OLIVEIRA, L., MARTINS, L. E. B., DA SILVA, E ET AL. Efeitos da fisioterapia cardiovascular em paciente 
submetido à valvoplastia aórtica: estudo de caso. Fisioterapia em Movimento, v. 19, n. 1, 2017.

[16] KLINKENBERG, T. J., VAN DER HORSTSCHRIVERS, A. N., BOUMA, W., ARIANI, M. A. Cardiac paraganglioma originating from the right coronary artery. European Journal of CardioThoracic Surgery, v. 51, n. 4, p. 803-803, 2017.

[17]FAZZIO, F. R. D., MATHEUS, F., CAMPOS, C. M., TAMAZATO, A. O., BUCHLER, G. D., ARRIETA, S. R., LEMOS, P. A. Anomalia da artéria coronária direita com origem no seio de Valsalva contralateral interpretada pelo método de identificação rápida angiográfico. Rev. Bras. Cardiol. Invasiva, v. 25, n. 14, p. 12-15, 2017.

[18] BU, H; ZHAO, T. Diagnóstico por Imagem: Origem Anômala da ACE Saindo do Tronco da Artéria Pulmonar. Arquivos Brasileiros de Cardiologia, v. 114, n. 4, p. 4-7, 2020.

[19] GROSSMAN, G. B. Perfusão Miocárdica por Tomografia Computadorizada: Mais Uma Peça no Tabuleiro. Arquivos Brasileiros de Cardiologia, v. 113, n. 6, p. 1102-1103, 2019.

[20] ANTONIO, R. S., DE OLIVEIRA FONSECA, A., FABRIS JR, J. F., RESENDE JR, V. P., DOS SANTOS, J. L. A., FERREIRA, R. D. S. A. Comunicação interc,22oronária: uma anomalia coronária rara. Revista Brasileira de Cardiologia Invasiva, v. 24, n. 1-4, p. 47-49, 2016.

[21] MATHEUS, F., FAZZIO, F. R. D., SALVADORI, F. A., TAMAZATO, A. O., BUCHLER, G. D., CAMPOS, C. A. H. D. M. Origem anômala da artéria coronária direita no seio de Valsalva esquerdo: prevalência, características clínicas e seguimento de longo prazo. J Transcat Intervent, v. 26, n. 1-2, p. -, 2018.

[22] OLIVEIRA, M. D. P., NAVARRO, E. C., ZAMPIER, L. B., SANTOS, L. F. M. D., PEDROSO, I. D. A., SÁ, G. A. D. Comunicação intercoronariana entre as artérias circunflexa e coronária direita: uma anomalia coronariana extremamente rara. J Transcat Intervent., v. 27, p. -, 2019.

[23] WAINSTEIN, R. V., VALLE, F. H., BERGOLI, L. C. C., MOSSMANN, M., GONÇALVES, S. C., WAINSTEIN, M. V. Intervenção coronária percutânea de múltiplos vasos em artéria coronária única. Rev. Bras. Cardiol. Invasiva, v. 25, n. 1-4, p. 49-51, 2017. 